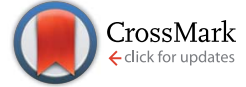

Cite this: RSC Adv., 2014, 4, 38663

\title{
The aqueous $N$-phosphorylation and $\mathrm{N}$-thiophosphorylation of aminonucleosides $\uparrow$
}

\author{
Louis P. Conway, Richard J. Delley, Jonathan Neville, Gemma R. Freeman, \\ Hannah J. Maple, Vincent Chan, Alexander J. Hall and David R. W. Hodgson*
}

Received 7th August 2013

We demonstrate $\mathrm{N}$-phosphorylation and $\mathrm{N}$-thiophosphorylation of unprotected aminonucleosides in aqueous media. $\mathrm{N}$-Phosphorylations using phosphoric chloride and $\mathrm{N}$-thiophosphorylations using thiophosphoryl chloride were explored as functions of $\mathrm{pH}$ using $5^{\prime}$-amino- $5^{\prime}$-deoxyguanosine as substrate. These reagents were compared to phosphodichloridate and thiophosphodichloridate ions, and the methodology was applied to other aminonucleosides. S-Alkylations of the nucleoside $\mathrm{N}$-thiophosphoramidates were investigated as functions of $\mathrm{pH}$ and alkylating agent.

carried out in water, with high conversion, and good $\mathrm{N}$-selectivity. ${ }^{14,15}$ The methodology was extended to the use of thiophosphoryl chloride as a (thio)phosphorylation agent on a series of generic amines, with the advantage that the thiophosphoramidates thus formed can then be $S$-alkylated to produce analogues of phosphodiester systems. ${ }^{19}$

Here we seek to explore, expand and optimise the aqueous phosphorylations and thiophosphorylations of aminonucleosides through $\mathrm{pH}$ control, and to compare phosphorylating and thiophosphorylating agents. We have also previously reported on the hydrolysis kinetics of phosphodichloridate $\left(\mathrm{Cl}_{2} \mathrm{OPO}^{-}\right)$ and thiophosphodichloridate $\left(\mathrm{Cl}_{2} \mathrm{SPO}^{-}\right)$ions, ${ }^{20}$ and here we assess their suitability as phosphorylating agents, compared to their counterparts $\mathrm{POCl}_{3}$ and $\mathrm{PSCl}_{3}$.

\section{Results and discussion}

\section{$\mathrm{pH}$ control and optimisation}

$5^{\prime}$-Amino-5'-deoxyguanosine $\mathbf{3}^{21}$ was used as a model substrate to determine $\mathrm{pH}$ optima for phosphorylation procedures. The $5^{\prime}$-amino-5'-deoxyguanosine 3 was dissolved in water and adjusted to a predetermined $\mathrm{pH}$ value with potassium hydroxide solution. A single equivalent of the phosphorylating agent in acetonitrile was then added slowly to the solution whilst the $\mathrm{pH}$ was kept constant using an autotitrator to add potassium hydroxide solution as required.

The $5^{\prime}$-amino-5'-deoxyguanosine 3 was either phosphorylated or thiophosphorylated using one of phosphoryl chloride $\mathbf{1}(\mathbf{O})$, thiophosphoryl chloride $\mathbf{1}(\mathbf{S})$, potassium phosphodichloridate $2(\mathrm{O})$ or potassium thiophosphodichloridate $2(\mathrm{~S})$ at $\mathrm{pH}$ values of 11, 11.5, 12, and 12.5 (Fig. 1). After addition of the phosphorylating/thiophosphorylating agent, the conversion levels were determined by ${ }^{31} \mathrm{P}$ NMR spectroscopy. The $N$-phosphoramidate and $\mathrm{N}$-thiophosphoramidate monoesters are unstable, except at high $\mathrm{pH},{ }^{14,22,23}$ making them difficult to
Department of Chemistry, Durham University, South Road, Durham, DH1 3LE, UK. E-mail: d.r.w.hodgson@durham.ac.uk; Tel: +44 (0)191 3342123

$\dagger$ Electronic supplementary information (ESI) available: NMR spectra. See DOI: $10.1039 / \mathrm{c} 4 \mathrm{ra} 08317 \mathrm{~b}$ 
<smiles>[Y][X]([X])(Cl)(Cl)(Cl)O[Na]</smiles>

$1(0) \& 1(\mathrm{~S})$<smiles>NCC1OC(O)C(n2cnc3c(=O)[nH]c(N)nc32)O1</smiles>

3
Fig. 1 The phosphosphorylating agents 1 and 2 used in this study, and the model substrate, $5^{\prime}$-amino- $5^{\prime}$-deoxyguanosine 3 .

isolate, however, $5^{\prime}$-amino- $5^{\prime}$-deoxyguanosine $5^{\prime}-N$-phosphoramidate has been isolated and characterised by ${ }^{31} \mathrm{P}$ NMR and ${ }^{1} \mathrm{H}$ NMR spectroscopies, and these data were used to corroborate the observed signals. ${ }^{14}$ The presence of the $N$-thiophosphoramidate was confirmed by trapping this reactive species through $S$-alkylation and isolating and characterising the stable adduct, in a manner analogous to our earlier report. ${ }^{22}$

Apart from the desired $\mathrm{N}$-phosphoramidate 5 and $\mathrm{N}$-thiophosphoramidate 8, we also observed the formation of bisaminolysis side products 6 and $\mathbf{9}$, in which the phosphorylating agent was attacked by two equivalents of amine, and inorganic phosphate 7 and thiophosphate 10, which result from the breakdown of the phosphorylating agents. These results mimic those we have seen previously for a range of generic amines 4 (Scheme 1). ${ }^{19,22}$

The results show optima at $\mathrm{pH} 12$ for each of the four (thio) phosphorylating agents $\mathbf{1}(\mathbf{O}), \mathbf{1}(\mathbf{S}), \mathbf{2}(\mathbf{O})$ and $\mathbf{2 ( S )}$ (Fig. 2). The

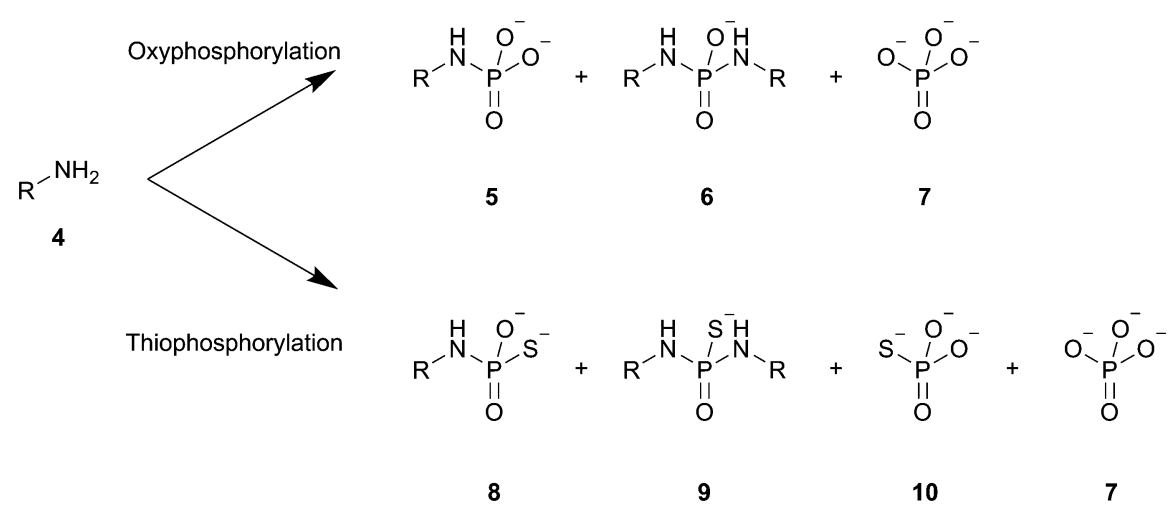

Scheme 1 The observed products and side-products of the phosphorylation and thiophosphorylation reactions. $\mathrm{R}=5^{\prime}$-deoxyguanosyl.
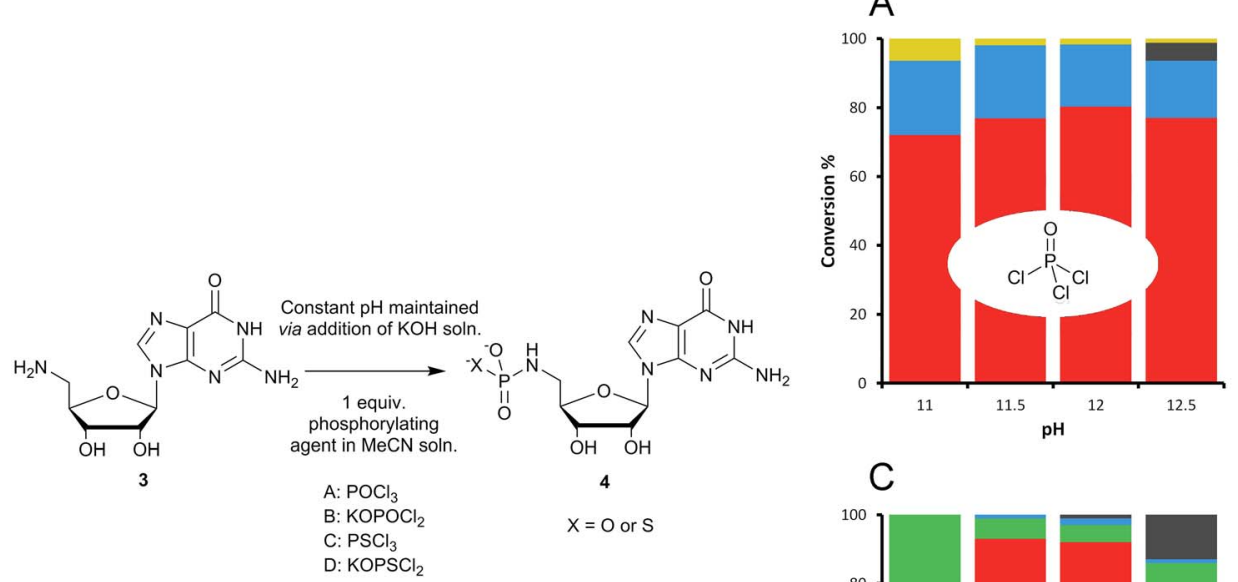

C

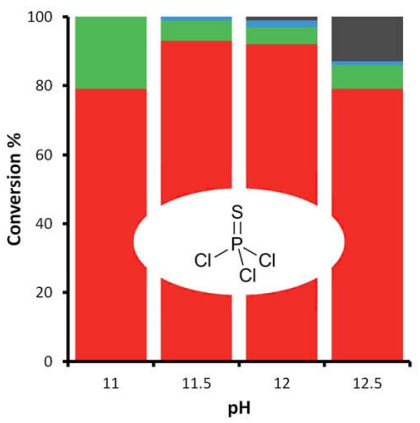

B

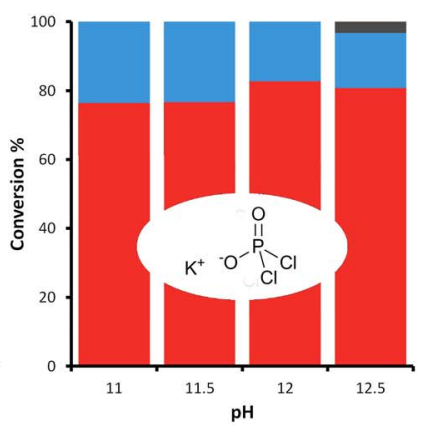

D

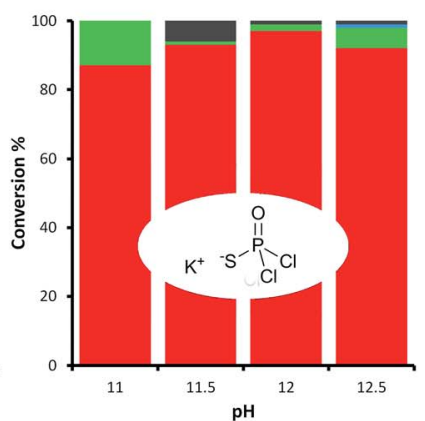

Fig. 2 The results of the $N$-phosphorylations and $N$-thiophosphorylations of $5^{\prime}$-amino-5'-deoxyguanosine. Notation: (red) product; (green) inorganic thiophosphate; (blue) inorganic phosphate; (yellow) bis product; (black) other. 
optima were especially pronounced for the thiophosphorylation reactions; the greatest levels of conversion were achieved using the thiophosphodichloridate ion $2(\mathbf{S})$, with a maximum of $97 \%$ conversion to thiophosphoramidate 8 at $\mathrm{pH} 12$, as opposed to $87 \%$ at $\mathrm{pH} 11$. The thiophosphorylation reactions with thiophosphoryl chloride $\mathbf{1}(\mathbf{S})$ reflect the same trend, with a maximum of $93 \%$ at $\mathrm{pH} 12$, and minimum of $79 \%$ at $\mathrm{pH} 11$.

The effect of $\mathrm{pH}$ on the oxyphosphorylation appears to be less pronounced. The greatest level of conversion was again achieved using the phosphodichloridate ion $2(\mathrm{O})$ at $\mathrm{pH} 12$, with $83 \%$ to $76 \%$ being observed over the tested $\mathrm{pH}$ range. The reactions with phosphoryl chloride $\mathbf{1}(\mathbf{O})$ were marginally poorer with conversions in the range $80 \%$ to $72 \%$. Analysis of the byproducts revealed a clear advantage to the use of the phosphodichloridate $2(\mathbf{O})$, namely, the lack of formation of bis aminolysis product $\mathbf{6}$.

Considering the structure of the substrate, $5^{\prime}$-amino- $5^{\prime}$ deoxyguanosine 3 and the (thio)phosphorylating agents, several factors could account for these trends. High $\mathrm{pHs}$ are required to stabilise the (thio)phosphoramidate products, however, they also serve to solubilise the $5^{\prime}$-amino- $5^{\prime}$-deoxyguanosine 3 substrate through ionisation of the $\mathrm{N}-\mathrm{H}$ of the guanine. At higher pHs, the ionisation of the cis-diol functionality could contribute to a change in reaction outcome $\left(\mathrm{p} K_{\mathrm{a}} \sim 12.5\right) .{ }^{24}$ In the case of the dichloridate ions $2(\mathrm{O})$ and 2(S), hydroxide-promoted hydrolysis of the (thio)phosphorylating agent is unlikely in light of our previous studies upon these species, which reveal flat pH- $k_{\text {obs }}$ profiles. $^{20}$ With trichlorides $\mathbf{1}(\mathbf{O})$ and $\mathbf{1}(\mathbf{S})$, their enhanced reactivity could render them more susceptible to hydrolysis, however, their hydrolysis products are the

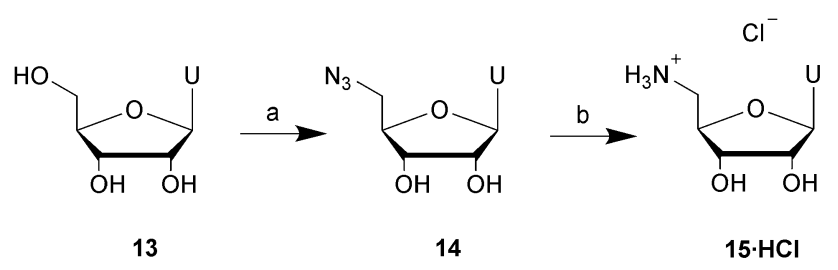

Scheme 2 The synthesis of $5^{\prime}$-amino- $5^{\prime}$-deoxyuridine, hydrochloride salt $15 \cdot \mathrm{HCl}$. Reagents and conditions: (a) $\mathrm{Ph}_{3} \mathrm{P}, \mathrm{CBr}_{4}, \mathrm{LiN}_{3}, \mathrm{DMF}, 4 \mathrm{~h}, \mathrm{rt}$; (b) (i) $\mathrm{Ph}_{3} \mathrm{P}$, pyridine, $2 \mathrm{~h}$, rt; (ii) $\mathrm{EtOH}, \mathrm{HCl}_{(\mathrm{g})}$. dichloridates 2(O) and 2(S), which permit additional opportunity for nucleophilic attack (loss of the "third" chloride is likely to be unselective towards the nature of the nucleophile, and thus would reflect nucleophile concentration, where water is clearly the most abundant entity). Solubility phenomena and the partitioning of reaction partners between different phases could also influence reaction outcome significantly, however, the effects of these properties are difficult to predict.

\section{Synthesis of other aminonucleosides}

Having established a single $\mathrm{pH}$ optimum across all four phosphorylating agents $\mathbf{1}(\mathbf{O}), \mathbf{1}(\mathbf{S}), \mathbf{2}(\mathbf{O})$ and $\mathbf{2 ( S )}$ using the model substrate $5^{\prime}$-amino- $5^{\prime}$-deoxyguanosine 3 , we applied the methodology to other nucleosides. Four aminonucleosides were prepared to test the generality of our finding: $5^{\prime}$-amino- $5^{\prime}$ deoxyadenosine 11, $3^{\prime}$-amino- $3^{\prime}$-deoxythymidine 12, $5^{\prime}$-amino$5^{\prime}$-deoxyuridine 15 and $5^{\prime}$-amino- $5^{\prime}$-deoxycytidine 20. The dihydrochloride salt of $5^{\prime}$-amino- $5^{\prime}$-deoxyadenosine 11 was synthesised according to a literature method..$^{25}$ The $3^{\prime}$-amino- $3^{\prime}$ deoxy analogue of thymidine $\mathbf{1 2}$ was synthesised starting from the commercially available $3^{\prime}$-azido-3'-deoxythymidine (AZT), based on a procedure by Pastor-Anglada et $a .^{26}$ and was precipitated as a hydrochloride salt $\mathbf{1 2} \cdot \mathbf{H C l}$.

$5^{\prime}$-Amino-5'-deoxyuridine was formed by adapting a single step procedure developed by Hata et al. to convert uridine to $5^{\prime}$ azido-5'-deoxyuridine $14,{ }^{27}$ which was reduced to the desired amine using triphenylphosphine, ${ }^{26}$ and isolated as its hydrochloride salt $\mathbf{1 5} \cdot \mathbf{H C l}$ (Scheme 2).

To our knowledge $5^{\prime}$-amino-5'-deoxycytidine 20 has not been reported. We protected the exocyclic amino group of cytosine 16 via benzoylation. ${ }^{28}$ The protection of the $2^{\prime}$ - and $3^{\prime}$-hydroxyl groups and the tosylation of the $5^{\prime}$-hydroxyl group were adapted from procedures developed by Winans and Bertozzi. ${ }^{29}$ The crude tosylated material was reacted with sodium azide in DMSO in an adapted literature procedure ${ }^{30}$ to afford azide 18 which was isolated by precipitation in a large volume of water. The protecting groups were removed, ${ }^{31}$ and $5^{\prime}$-azide 19 was isolated by cation exchange chromatography. The azide was then reduced with triphenylphosphine ${ }^{26}$ and the amine was isolated as the dihydrochloride salt $\mathbf{2 0} \cdot \mathbf{2 H C l}$ (Scheme 3).

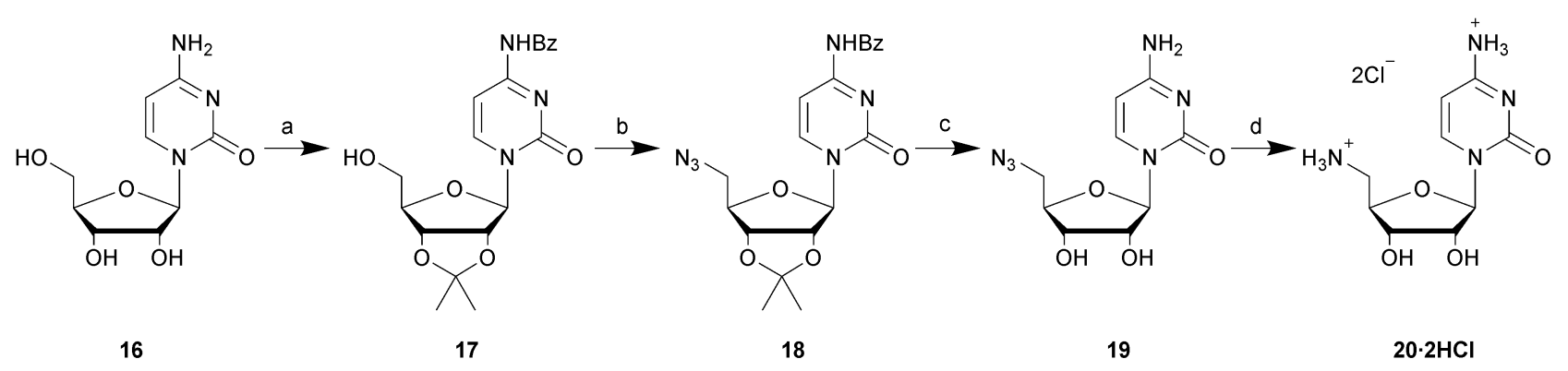

Scheme 3 The synthesis of $5^{\prime}$-amino-5'-deoxycytidine, dihydrochloride salt $20 \cdot 2 \mathrm{HCl}$. Reagents and conditions: (a) (i) benzoic anhydride, $\mathrm{MeOH}$, $5 \mathrm{~h}$, reflux; (ii) 2,2-dimethoxypropane, TsOH, $4 \AA$ mol sieves, DMF, $2 \mathrm{~h}, 40{ }^{\circ} \mathrm{C}$; (b) (i) $\mathrm{Ts}_{2} \mathrm{O}$, pyridine, $\mathrm{CH}_{2} \mathrm{Cl}_{2}, 2.5 \mathrm{~h}$, reflux; (ii) NaN3$, \mathrm{DMSO}, 2 \mathrm{~h} 20$ min, $70{ }^{\circ} \mathrm{C}$; (c) (i) $\mathrm{MeOH}, \mathrm{NH}_{4} \mathrm{OH}, 18 \mathrm{~h}$, rt; (ii) trifluoroacetic acid, $\mathrm{H}_{2} \mathrm{O}, 3 \mathrm{~h}$, rt; (iii) ion exchange chromatography; (d) (i) $\mathrm{Ph}_{3} \mathrm{P}$, pyridine, $3 \mathrm{~h}$, rt; (ii) $\mathrm{EtOH}, \mathrm{HCl}_{(\mathrm{g})}$. 


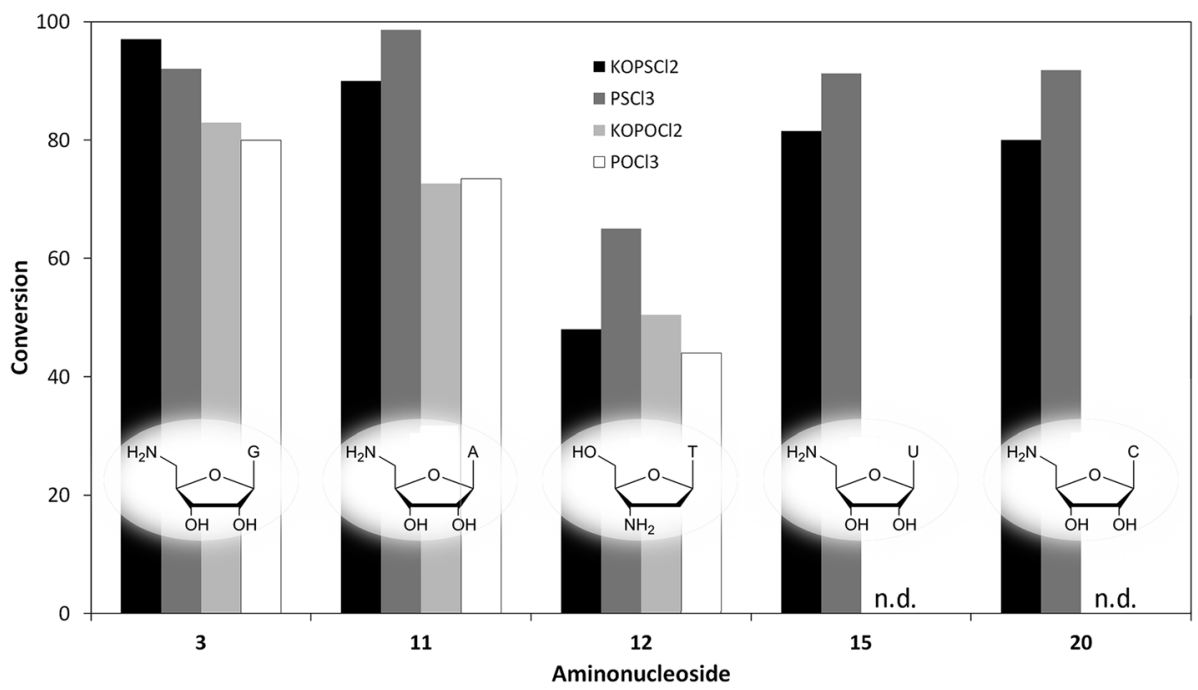

Fig. 3 Conversion levels for the $N$-phosphorylations and $N$-thiophosphorylations of $5^{\prime}$-amino- $5^{\prime}$-deoxyguanosine $3,5^{\prime}$-amino-5'-deoxyadenosine 11, $3^{\prime}$-amino-3'-deoxythymidine 12, 5'-amino-5'-deoxyuridine 15, and $5^{\prime}$-amino-5'-deoxycytidine 20.

\section{Aminonucleoside phosphorylations and thiophosphorylations}

The thiophosphorylations were carried out using both thiophosphoryl chloride $\mathbf{1}(\mathbf{S})$ and thiophosphodichloridate 2(S) on $5^{\prime}$-amino-5'-deoxyadenosine $\mathbf{1 1}, 5^{\prime}$-amino-5'-deoxycytidine $\mathbf{2 0}$, $3^{\prime}$-amino-3'-deoxythymidine $\mathbf{1 2}$, and $5^{\prime}$-amino- $5^{\prime}$-deoxyuridine 15. The oxyphosphorylations were performed using both oxyphosphorylating agents $\mathbf{1}(\mathbf{O})$ and $2(0)$ on $5^{\prime}$-amino-5'-deoxyadenosine 11 and $3^{\prime}$-amino-3'-deoxythymidine $\mathbf{1 2}$. In every case, one equivalent of phosphorylating agent was used, and the phosphorylations were performed at $\mathrm{pH} 12$, based on the findings of our optimisation experiments (Scheme 4).

The conversion levels observed in the experiments are shown in Fig. 3. For the thiophosphorylations, conversions were generally high, especially for the reactions of $5^{\prime}$-amino- $5^{\prime}$-deoxyguanosine 3 with thiophosphodichloridate 2(S) and $5^{\prime}$-amino-5'deoxyadenosine $\mathbf{1 1}$ with thiophosphoryl chloride $\mathbf{1 ( S )}$, with conversions of $97 \%$ and $99 \%$ respectively. A notable exception to the high thiophosphorylation conversions is the reaction with $3^{\prime}$-amino- $3^{\prime}$-deoxythymidine 12 ; this is likely due to the more sterically hindered environment of the $3^{\prime}$-amine nucleophile in this example.

The use of thiophosphoryl chloride $\mathbf{1}(\mathbf{S})$ gave greater levels of conversion than the thiophosphodichloridate ion $2(\mathbf{S})$, with the exception of the reaction with $5^{\prime}$-amino-5'-deoxyguanosine 3 . Unlike the thiophosphodichloridate ion, thiophosphoryl chloride shows very limited solubility in water. This may give rise to the improved selectivity, despite thiophosphoryl chloride's greater reactivity, possibly through reaction at solvent-water interfaces rather than in homogeneous solution.

In other cases, the use of potassium thiophosphodichloridate 2(S) afforded fewer side-products such as the bis thiophosphoramidate 9. For the oxyphosphorylating agents $\mathbf{1}(\mathbf{O})$ and 2(O), the trend appears to be reversed; the phosphodichloridate $2(\mathrm{O})$ reactions tended to give the greatest levels of conversion, possibly due to the reduced reactivity of $2(\mathbf{O})$ allowing better mixing and thus greater selectivity than with phosphoryl chloride $\mathbf{1}(\mathbf{O})$. In general, the levels of conversion for the oxyphosphorylations are more modest than those of the thiophosphorylations with a maximum of $83 \%$ for the reaction of $5^{\prime}$-amino-5'-deoxyguanosine 3 with phosphodichloridate 2(O). 3'-Amino-3'-deoxythymidine again showed the poorest conversions, at $44 \%$ and $51 \%$ for the reactions with phosphorylating agents $\mathbf{1}(\mathbf{O})$ and $2(0)$ respectively.

\section{Thiophosphoramidate $S$-alkylation}

The $S$-Alkylation of thiophosphoramidates $21 a-d(S)$ could provide access to mimics of naturally occurring phosphodiesters such as CMP-Neu5Ac or analogues for mechanistic studies. ${ }^{4}$ Additionally, there are many commercially available alkylating agents, and this reaction could allow the rapid

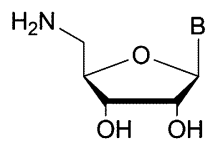

$11,15,20$

or

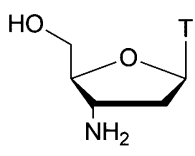

12

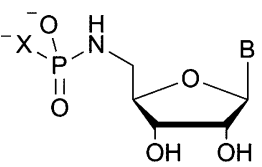

$21 \mathrm{a}(\mathrm{X}) \mathrm{B}=$ adenine $21 \mathrm{~b}(\mathrm{X}) \mathrm{B}=$ cytosine $21 \mathrm{C}(\mathrm{X}) \mathrm{B}=$ uracil $\mathrm{X}=\mathrm{O}$ or $\mathrm{S}$

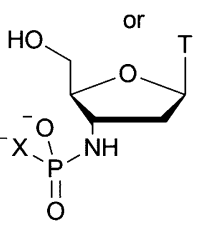

$X=O 21 d(0)$ or $\mathrm{S} 21 \mathrm{~d}(\mathrm{~S})$
Scheme 4 The $N$-phosphorylations and $N$-thiophosphorylations of $5^{\prime}$-amino-5'-deoxyadenosine $11, \quad 3^{\prime}$-amino- $3^{\prime}$-deoxythymidine 12 , $5^{\prime}$-amino- $5^{\prime}$-deoxyuridine 15 , and $5^{\prime}$-amino- $5^{\prime}$-deoxycytidine 20 


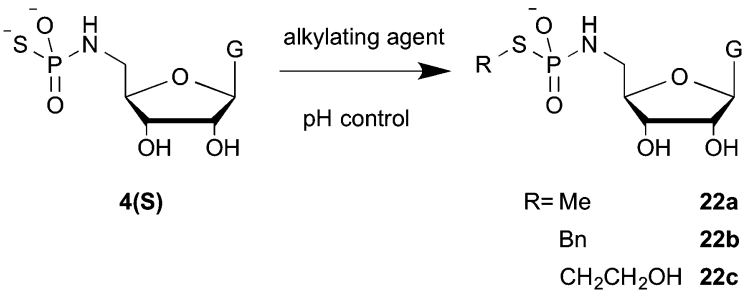

Scheme 5 The alkylation of $5^{\prime}$-deoxyguanosine 5'-thiophosphoramidate 4(S). Reagents and conditions: (a) Mel to give 22a; (b) $\mathrm{BnCl}$ to give $22 \mathrm{~b}$; or bromoethanol to give $22 \mathrm{c}$.

development of a diverse range of derivatives. We conducted preliminary studies in this vein recently, where the products of the $N$-thiophosphorylation- $S$-alkylation of $5^{\prime}$-amino-5'-deoxyguanosine $\mathbf{3}$ and $5^{\prime}$-amino- $5^{\prime}$-deoxyadenosine $\mathbf{1 1}$ were prepared and isolated from non-pH-controlled reactions, and these results served as our starting point. ${ }^{22}$ Here we investigate the $\mathrm{pH}$ optimisation of this procedure. Using our model substrate, $5^{\prime}$ amino-5'-deoxyguanosine 3 , we performed $N$-thiophosphorylation, and the resulting nucleoside- $N$-thiophosphoramidate anion was then $S$-alkylated with one of three alkylating agents, each at fixed pHs using an autotitrator (Scheme 5).

We chose benzyl chloride, methyl iodide, and 2-bromoethanol as alkylating agents, using guanosine- $N$-thiophosphoramidate $\mathbf{4 ( S )}$ as the substrate. Guanosine- $N$-thiophosphoramidate $\mathbf{4 ( S )}$ was prepared under optimised conditions, where $>95 \%$ of the product represented the desired material, and this material was used directly in $S$-alkylation procedures. The conversion levels determined by ${ }^{31} \mathrm{P}$ NMR spectroscopy for each of the alkylating agents at each $\mathrm{pH}$ are illustrated in Fig. 4.

To confirm the intermediacy of the unstable, unalkylated precursor $N$-thiophosphoramidate $\mathbf{4 ( S ) , ~ t h r e e ~} S$-alkylation experiments were performed on $\mathbf{4}(\mathbf{S})$ at $\mathrm{pH} 12$, and the products were isolated by ion exchange chromatography and characterised. Isolated yields of $95 \%, 63 \%$, and $74 \%$ were recorded for the $S$-methyl 22a, benzyl 22b, and ethan-2-ol 22c systems. $S$-Alkylation efficiency appeared to be largely unaffected by $\mathrm{pH}$, at least within the range that we studied, with conversions levels being $\sim 80 \%$. Surprisingly, $S$-alkylation occurs at lower conversion levels than $N$-thiophosphorylation, which may be due, in part, to the hydrolysis of the desired products under the high $\mathrm{pH}$ conditions. In particular, the formation of a nascent "good" thiolate leaving group through $S$-alkylation could represent a likely pathway for hydrolysis, and we are currently studying the hydrolysis kinetics of the $S$-alkylated thiophosphoramidates to give greater insight.

\section{Conclusions}

Effective $N$-oxyphosphorylation and $N$-thiophosphorylation of aminonucleosides 3, 11, 12, 15 and 20 was achieved through $\mathrm{pH}$ control, with high levels of conversion. Phosphodichloridates 2(O) and 2(S) were competent alternative phosphorylation agents, that eliminated the formation of undesired bis-amino(thio)phosphoramidates, while retaining similar levels of conversion. The $S$-alkylation of guanosine- $N$-thiophosphoramidate 4(S) showed no significant $\mathrm{pH}$-sensitivity across the $\mathrm{pH}$ range 9-12, although conversion levels were not quantitative. The combination of efficient $N$-(thio)phosphorylation and $S$-alkylation gives straightforward access to phosphodiester mimics from a range of unprotected aminonucleosides derived from the common nucleobases.

\section{Experimental}

\section{N4-Benzoylcytidine}

In an adapted literature procedure ${ }^{28}$ cytidine $(2.784 \mathrm{~g}, 11.4$ $\mathrm{mmol})$ and benzoic anhydride $(2.818 \mathrm{~g}, 12.5 \mathrm{mmol})$ were placed in a round bottomed flask with dry methanol $(300 \mathrm{ml})$ and heated at reflux with stirring. After $1 \mathrm{~h}$, additional benzoic anhydride $(2.774 \mathrm{~g}, 12.3 \mathrm{mmol})$ was added, followed by further additions $(2.785 \mathrm{~g}, 12.3 \mathrm{mmol}$ after $2 \mathrm{~h}, 2.794 \mathrm{~g}, 12.4 \mathrm{mmol}$ after $3 \mathrm{~h}$ ). Heating was maintained for a total of $5 \mathrm{~h}$. After allowing the reaction vessel to cool for $18 \mathrm{~h}$, the precipitate was collected by vacuum filtration. Drying over $\mathrm{P}_{2} \mathrm{O}_{5}$ under vacuum yielded the desired product $(2.786 \mathrm{~g}, 70 \%), \mathrm{mp} 236-238{ }^{\circ} \mathrm{C}$ (from methanol) (lit., ${ }^{32} 238-240{ }^{\circ} \mathrm{C}$ ); $\nu_{\max } / \mathrm{cm}^{-1} 3421,3307,3161,1644$ $(\mathrm{CO}) ; \delta_{\mathrm{H}}\left(400 \mathrm{MHz},\left(\mathrm{CD}_{3}\right)_{2} \mathrm{SO}\right) 3.61$ (1H, ddd, $J$ 12.3, 5.2, 3.1,
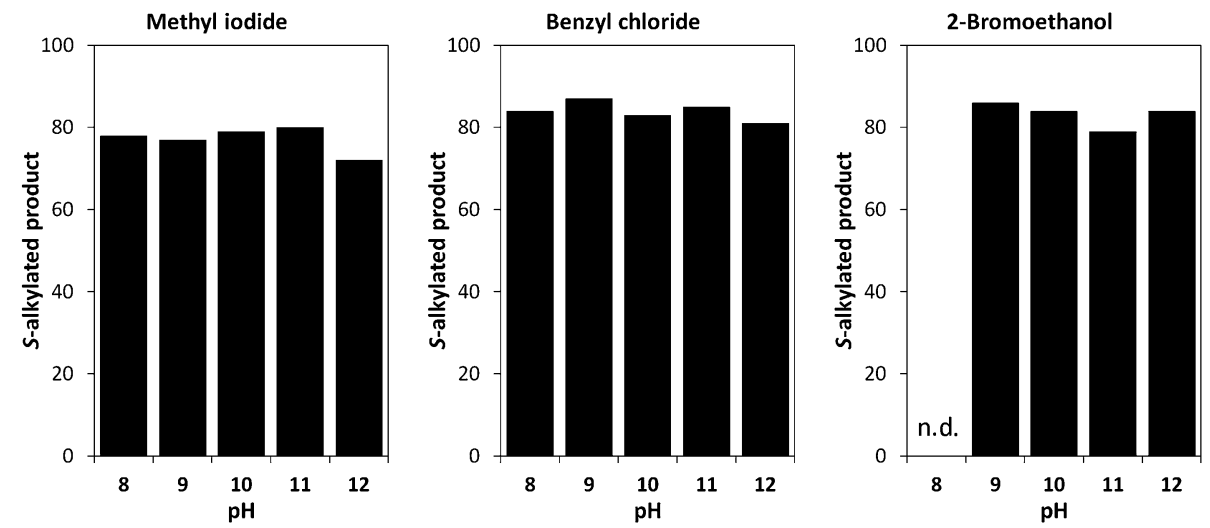

Fig. 4 The conversion levels by ${ }^{31} \mathrm{P}$ NMR spectroscopy of $S$-alkylations of guanosine- $N$-thiophosphoramidate $4(\mathrm{~S})$ to $S$-alkylthiophosphoramidates 22a-c using methyl iodide, benzyl chloride, and 2-bromoethanol, respectively. 
$\left.\mathrm{C} 5^{\prime}-\mathrm{H}_{\alpha}\right), 3.76\left(1 \mathrm{H}, \mathrm{ddd}, J 12.3,5.2,2.8, \mathrm{C}^{\prime}-\mathrm{H}_{\beta}\right), 3.92(1 \mathrm{H}, \mathrm{td}, J 5.9$, 2.9, C4'-H), 3.95-4.05 (2H, m, C2'-H, C3'-H), 5.05 (1H, d, J 5.7, $\left.\mathrm{C}^{\prime}-\mathrm{OH}\right), 5.18(1 \mathrm{H}$, app t, $J$ 5.1, C5' $-\mathrm{OH}), 5.51\left(1 \mathrm{H}, \mathrm{d}, J 4.8, \mathrm{C}^{\prime}-\right.$ $\mathrm{OH}), 5.81\left(1 \mathrm{H}, \mathrm{d}, J 2.9, \mathrm{C1}^{\prime}-\mathrm{H}\right), 7.34(1 \mathrm{H}, \mathrm{d}, J 7.5, \mathrm{C} 5-\mathrm{H}), 7.52(2 \mathrm{H}$, $\mathrm{dd}, J$ 7.1, 8.4, $m$-Ph), 7.63 (1H, t, J 7.4, p-Ph), 8.00 (2H, d, J 7.5, o$\mathrm{Ph}), 8.51$ (1H, d, $J$ 7.5, C6-H), $11.25(1 \mathrm{H}, \mathrm{s}, \mathrm{NH}) ; \delta_{\mathrm{C}}(126 \mathrm{MHz}$, $\left.\left(\mathrm{CD}_{3}\right)_{2} \mathrm{SO}\right)$ 60.6, 69.3, 75.3, 84.9, 90.9, 96.6, 110.0, 129.2, 133.5, 133.8, 146.1, 155.4, 163.8, 168.0; $\mathrm{m} / \mathrm{z} 346.2$ (M - H, 100\%) 347.2 (26) 693 (22).

\section{N4-Benzoyl-2' ${ }^{\prime} 3^{\prime}$-O-isopropylidenecytidine (17)}

In an adapted literature procedure ${ }^{29} \mathrm{~N} 4$-benzoylcytidine $(2.79 \mathrm{~g}$, $8.03 \mathrm{mmol}), 2$ 2-dimethoxypropane $(11 \mathrm{ml}), 4 \AA$ molecular sieves, and tosic acid monohydrate $(0.45 \mathrm{~g}, 2.37 \mathrm{mmol})$ were placed in a round-bottomed flask with DMF $(44 \mathrm{ml})$. The mixture was heated at $40{ }^{\circ} \mathrm{C}$ for $2.5 \mathrm{~h}$, before Amberlyst ${ }^{\circledR} \mathrm{A}-21$ anion exchanger ( $1.19 \mathrm{~g}$ ) was added and heating was continued for a further $30 \mathrm{~min}$. The mixture was filtered through Celite ${ }^{\circ}$, the solvent was then removed under vacuum from the filtrate, and the residue was recrystallised from water to yield the product $(2.375 \mathrm{~g}, 76 \%)$; $\mathrm{mp} 163-165{ }^{\circ} \mathrm{C} ; \nu_{\max } / \mathrm{cm}^{-1} 1652$ (CO), 1482,$1303 ; \delta_{\mathrm{H}}\left(400 \mathrm{MHz}, \mathrm{CDCl}_{3}\right) 1.37\left(3 \mathrm{H}, \mathrm{s}, \mathrm{CH}_{3 \alpha}\right), 1.63(3 \mathrm{H}, \mathrm{s}$, $\left.\mathrm{CH}_{3 \beta}\right), 3.54\left(1 \mathrm{H}\right.$, br s, C5'-OH), 3.80-3.89 (1H, m, C5' $\left.-\mathrm{H}_{\alpha}\right), 3.97$ $\left(1 \mathrm{H}, \mathrm{dd}, J 12.2,2.3, \mathrm{C}^{\prime}-\mathrm{H}_{\beta}\right), 4.40\left(1 \mathrm{H}\right.$, app q, $\left.J 3.0, \mathrm{C}^{\prime}-\mathrm{H}\right), 5.09$ (1H, dd, J 6.4, 3.3, C3'-H), 5.25 (1H, dd, J 6.6, 2.6, C2'-H), 5.55 $(1 \mathrm{H}, \mathrm{d}, J$ 2.7, C1'-H), $7.52(2 \mathrm{H}, \mathrm{d}, J$ 7.8, $m-\mathrm{Ph}), 7.63(1 \mathrm{H}, \mathrm{t}, J$ 7.4, $p-\mathrm{Ph}), 7.81(1 \mathrm{H}, \mathrm{d}, J 7.4, \mathrm{C} 6-\mathrm{H}), 7.89(2 \mathrm{H}, \mathrm{d}, J 7.5, o-\mathrm{Ph}), 8.77(1 \mathrm{H}$, $\mathrm{s}, \mathrm{NH}) ; \delta_{\mathrm{C}}\left(126 \mathrm{MHz}, \mathrm{CDCl}_{3}\right)$ 25.2, 27.3, 62.9, 80.5, 83.6, 88.1, 99.0, 100.0, 112.8, 114.1, 127.3, 127.6, 128.6, 129.1, 133.4, 143.3, $166.1 ; \mathrm{m} / \mathrm{z} 388.1500\left(\mathrm{M}+\mathrm{H}^{+}, 20 \%\right)$, requires 388.1509, 410.1325 $\left(\mathrm{M}+\mathrm{Na}^{+}, 100\right)$.

\section{N4-Benzoyl-2', $3^{\prime}$ - O-isopropylidene-5' $-O$ - toluenesulfonylcytidine}

N4-Benzoyl-2', $3^{\prime}$-O-isopropylidenecytidine $(2.10 \mathrm{~g}, 5.42 \mathrm{mmol})$, 4-toluenesulfonyl chloride $(2.44 \mathrm{~g}, 12.9 \mathrm{mmol})$, pyridine $(20 \mathrm{ml})$ and DCM $(40 \mathrm{ml})$ were placed in a round-bottomed flask and heated at reflux for $2.5 \mathrm{~h}$. The solution was then diluted with chloroform $(120 \mathrm{ml})$ and washed with hydrochloric acid $(0.5 \mathrm{M}$, $5 \times 50 \mathrm{ml}$ ) and saturated sodium hydrogencarbonate solution $(2 \times 50 \mathrm{ml})$. The organic layer was dried over $\mathrm{MgSO}_{4}$ and the solvent was removed under vacuum to yield the crude product, which was used in the next reaction without further purification. (1.53 g).

\section{5'-Azido-5'-deoxy-N4-benzoyl-2', $3^{\prime}$-O-isopropylidenecytidine}

(18)

Adapting a literature procedure, ${ }^{30} \mathrm{N4}$-benzoyl-2', $3^{\prime}$-O-isopropylidene- $5^{\prime}$-O-toluenesulfonylcytidine (1.08 g, $\left.1.99 \mathrm{mmol}\right)$ and sodium azide $(579 \mathrm{mg}, 8.91 \mathrm{mmol})$ were placed in a flask with DMSO $(10 \mathrm{ml})$ and heated at $70{ }^{\circ} \mathrm{C}$ for $2 \mathrm{~h} 20 \mathrm{~min}$. The solution was then added to $\mathrm{H}_{2} \mathrm{O}(550 \mathrm{ml})$ and left to stir for $18 \mathrm{~h}$. The precipitated product was then isolated by vacuum filtration. (430 mg, 52\%); mp 163-165 ${ }^{\circ} \mathrm{C} ; \nu_{\max } / \mathrm{cm}^{-1} 3354,1640$ (CO), $1485 ; \delta_{\mathrm{H}}\left(400 \mathrm{MHz}, \mathrm{CDCl}_{3}\right) 1.37\left(3 \mathrm{H}, \mathrm{s}, \mathrm{CH}_{3 \alpha}\right), 1.60\left(3 \mathrm{H}, \mathrm{s}, \mathrm{CH}_{3 \beta}\right)$, $3.65\left(1 \mathrm{H}, \mathrm{dd}, J 12.8,4.4, \mathrm{C}^{\prime}-\mathrm{H}_{\alpha}\right), 3.76$, (1H, dd, $J$ 12.8, 6.8,
$\left.\mathrm{C}^{\prime}-\mathrm{H}_{\beta}\right)$ 4.31-4.36 (1H, m, C4'-H), $4.90\left(1 \mathrm{H}, \mathrm{dd}, J 6.4,4.0, \mathrm{C}^{\prime}-\mathrm{H}\right)$, 5.11-5.15 (1H, m, C3'-H), $5.70\left(1 \mathrm{H}, \mathrm{d}, J 1.5, \mathrm{C1}^{\prime}-\mathrm{H}\right), 7.53(2 \mathrm{H}, \mathrm{t}, J$ 7.6, $m-\mathrm{Ph}), 7.63$ (1H, t, J 7.4, p-Ph), 7.77 (1H, d, J 7.4, C6-H), 7.89 $(2 \mathrm{H}, \mathrm{d}, J$ 7.2, $o-\mathrm{Ph}), 8.67(1 \mathrm{H}, \mathrm{s}, \mathrm{NH}) ; \delta_{\mathrm{C}}\left(100 \mathrm{MHz}, \mathrm{D}_{2} \mathrm{O}\right) 25.2$, 27.3, 62.8, 77.2, 80.5, 83.8, 88.1, 97.0, 98.7, 114.1, 127.7, 129.1, 132.7, 133.4, 147.8, 163.1; $m / z$ 413.1585 ( $\left.\mathrm{M}+\mathrm{H}^{+}, 100 \%\right)$, requires 413.1573, $435.1406\left(\mathrm{M}+\mathrm{Na}^{+}, 40 \%\right)$.

\section{5'-Azido-5'-deoxycytidine (19)}

Based on a literature procedure, ${ }^{31} 5^{\prime}$-Azido- $5^{\prime}$-deoxy- $N 4$-benzoyl$2^{\prime}, 3^{\prime}$-O-isopropylidene cytidine $(732 \mathrm{mg}, 1.78 \mathrm{mmol})$ was placed in a round-bottomed flask with a $1: 1$ mixture of methanol and concentrated ammonium hydroxide $(90 \mathrm{ml})$ and was stirred at room temperature for $18 \mathrm{~h}$. The solvents were removed under vacuum, and the residue was stirred in a 9:1 mixture of trifluoroacetic acid and $\mathrm{H}_{2} \mathrm{O}$ for $3 \mathrm{~h}$ at room temperature before the solvents were removed under vacuum. The residue was dissolved in $\mathrm{H}_{2} \mathrm{O}$ and introduced to a protonated SP Sepharose ${ }^{\circledR}$ Fast Flow cation exchange column $(1.6 \mathrm{~cm}$ i.d. $\times 22 \mathrm{~cm}, 5 \mathrm{ml}$ $\min ^{-1}$ flow rate). The nucleoside was eluted with a $3 \%$ ammonium hydroxide solution (diluted from 35\% (w/w) ammonium hydroxide solution) and the eluted fractions were freeze-dried. The residue was then dissolved in methanol and filtered, and the solvent was removed from the filtrate under vacuum to give the solid product. (334 mg, 70\%); $\nu_{\max } / \mathrm{cm}^{-1} 2104\left(\mathrm{~N}_{3}\right), 1645$ (CO), 1438; $\delta_{\mathrm{H}}\left(400 \mathrm{MHz}, \mathrm{D}_{2} \mathrm{O}\right) 3.64\left(1 \mathrm{H}, \mathrm{dd}, J 13.7,5.0, \mathrm{C}^{\prime}-\mathrm{H}_{\alpha}\right)$, $3.78\left(1 \mathrm{H}, \mathrm{dd}, J 13.7,3.1, \mathrm{C}^{\prime}-\mathrm{H}_{\beta}\right), 4.14-4.19\left(1 \mathrm{H}, \mathrm{m}, \mathrm{C} 4^{\prime}-\mathrm{H}\right), 4.21$ (1H, dd, J 6.2, 5.3, C3'-H), 4.34 (1H, dd, J 5.3, 4.0, C2'-H), 5.87 $\left(1 \mathrm{H}, \mathrm{d}, J 4.0, \mathrm{C1}^{\prime}-\mathrm{H}\right), 6.03(1 \mathrm{H}, \mathrm{d}, J 7.5, \mathrm{C} 5-\mathrm{H}), 7.74(1 \mathrm{H}, \mathrm{d}, J 7.6$, C6-H); $\delta_{\mathrm{C}}\left(100 \mathrm{MHz}, \mathrm{D}_{2} \mathrm{O}\right)$ 51.2, 69.9, 73.3, 81.5, 90.5, 96.3, 141.6, 157.4, 163.8; $m / z 267.2$ (M - H, 100\%) 268.3 (15).

\section{5'-Amino-5'-deoxycytidine, hydrochloride salt $(20 \cdot 2 \mathrm{HCl})$}

5'-Azido-5'-deoxycytidine (400 $\mathrm{mg}, 1.49 \mathrm{mmol}$ ) was placed in a flask with triphenylphosphine $(790 \mathrm{mg}, 3.01 \mathrm{mmol})$ and pyridine $(6 \mathrm{ml})$. The solution was stirred at room temperature for 3 $\mathrm{h}$ before further triphenylphosphine $(791 \mathrm{mg}, 3.02)$ and pyridine $(6 \mathrm{ml})$ were added. The solution was stirred for an additional $3 \mathrm{~h}$ at room temperature before ammonia solution $(50 \mathrm{ml}$, $35 \% \mathrm{w} / \mathrm{w}$ ) was added, whereupon immediate precipitation was observed. The mixture was stirred overnight before being diluted with water $(100 \mathrm{ml})$ and extracted with chloroform $(3 \times$ $100 \mathrm{ml}$ ). Residual chloroform was removed from the aqueous layer under vacuum, and the aqueous extracts were lyophilised. The resulting solid was dissolved in ethanol $(60 \mathrm{ml})$ and hydrogen chloride gas was bubbled through the solution. The addition of diethyl ether $(300 \mathrm{ml})$ precipitated the product, which was isolated by filtration, washed with a small quantity of diethyl ether, and dried under vacuum overnight (382 mg, 81\%); mp 190-191 ${ }^{\circ} \mathrm{C}$ (decomp.) (from ethanol); $\nu_{\max } / \mathrm{cm}^{-1} 3118,3046$, $1715,1673,1404 ; \delta_{\mathrm{H}}\left(400 \mathrm{MHz}, \mathrm{D}_{2} \mathrm{O}\right) 3.34(1 \mathrm{H}, \mathrm{dd}, J$ 13.6, 9.4, $\left.\mathrm{C5}^{\prime}-\mathrm{H}_{\alpha}\right), 3.47\left(1 \mathrm{H}, \mathrm{dd}, J 13.6,3.0, \mathrm{C}^{\prime}-\mathrm{H}_{\beta}\right), 4.18-4.31\left(2 \mathrm{H}, \mathrm{m}, \mathrm{C}^{\prime}-\right.$ $\left.\mathrm{H}, \mathrm{C} 4^{\prime}-\mathrm{H}\right), 4.51$ (1H, dd, J 3.4, 5.5, C2'-H), 5.77 (1H, d, J 3.4, C1'$\mathrm{H}), 6.24\left(1 \mathrm{H}, \mathrm{d}, J\right.$ 7.9, C5-H), $7.87\left(1 \mathrm{H}, \mathrm{d}, J\right.$ 7.9, C6-H); $\delta_{\mathrm{C}}$ (100 MHz, $\left.\mathrm{D}_{2} \mathrm{O}\right)$ 41.9, 71.4, 73.5, 80.2, 94.1, 95.8, 137.8, 145.9, 
160.9; $\mathrm{m} / \mathrm{z} 243.1095\left(\mathrm{M}+\mathrm{H}^{+}, 50 \%\right)$, requires 243.1093, 265.0907 $\left(\mathrm{M}+\mathrm{Na}^{+}, 100\right)$.

\section{3'-Amino-3'-deoxythymidine, hydrochloride salt $(12 \cdot \mathrm{HCl})$}

Adapting a literature procedure, ${ }^{26} 3^{\prime}$-amino-3'-deoxythymidine $(1.00 \mathrm{~g}, 3.74 \mathrm{mmol})$ and triphenylphosphine $(1.54 \mathrm{~g}, 5.87 \mathrm{mmol})$ were dissolved in pyridine $(8 \mathrm{ml})$ and stirred at room temperature for $1 \mathrm{~h}$. Ammonia solution (30 ml, 35\%) was then added, and the mixture left to stir overnight. The suspension was diluted with water $(30 \mathrm{ml})$ and extracted with chloroform $(3 \times$ $30 \mathrm{ml}$ ) before being lyophilised. The solid residue was dissolved in ethanol $(100 \mathrm{ml})$ and hydrogen chloride gas was bubbled through the solution until precipitation was observed. The precipitate was isolated by filtration, and washed with a small quantity of diethyl ether. Additional product was obtained by adding diethyl ether $(500 \mathrm{ml})$ to the filtrate, and again filtering and washing the precipitate. The isolated solids were combined and dried under vacuum overnight yielding a total of $846 \mathrm{mg}$, 81\%; mp 253-255 ${ }^{\circ} \mathrm{C}$ (decomp.) (from ethanol); $\nu_{\max } / \mathrm{cm}^{-1} 3392$, $3032,1694,1644,1470 . \delta_{\mathrm{H}}\left(400 \mathrm{MHz}, \mathrm{D}_{2} \mathrm{O}\right) 1.86\left(3 \mathrm{H}, \mathrm{s}, \mathrm{C} 5-\mathrm{CH}_{3}\right)$, 2.54-2.70 (2H, m, C2'- $\left.\mathrm{H}_{\mathrm{a}} \mathrm{H}_{\mathrm{b}}\right), 3.81\left(1 \mathrm{H}, \mathrm{dd}, J 12.6,4.6, \mathrm{C}^{\prime}-\mathrm{H}_{\alpha}\right)$, $3.89\left(1 \mathrm{H}, \mathrm{dd}, J 12.6,3.4, \mathrm{C}^{\prime}-\mathrm{H}_{\beta}\right), 4.06(1 \mathrm{H}, \mathrm{dt}, J$ 8.1, 5.5, C3'-H), 4.19-4.28 (1H, m, C4'-H), 6.25-6.32 (1H, t, J 6.8, C1'-H), $7.62(1 \mathrm{H}$, d, $J$ 1.1, C6-H); $\delta_{\mathrm{C}}\left(100 \mathrm{MHz}, \mathrm{D}_{2} \mathrm{O}\right) 10.5,33.8,49.1,59.7,81.5$, 84.1, 110.5, 136.6, 150.5, 165.4; $\mathrm{m} / \mathrm{z} 242.1142\left(\mathrm{M}+\mathrm{H}^{+}, 100 \%\right)$, requires 242.1141, 264.0961 $\left(\mathrm{M}+\mathrm{Na}^{+}, 90\right)$.

\section{Lithium azide}

Following a literature procedure, ${ }^{33}$ sodium azide $(6.52 \mathrm{~g}, 100$ $\mathrm{mmol})$ and lithium sulfate $(6.90 \mathrm{~g}, 62.8 \mathrm{mmol})$ were co-dissolved in water $(35 \mathrm{ml})$ and stirred for $10 \mathrm{~min}$. Ethanol $(175 \mathrm{ml})$ was slowly added, and the mixture was stirred for a further $10 \mathrm{~min}$. The precipitate was removed by filtration, and the solvent was removed from the filtrate under vacuum. The solid residue was dried on the high vacuum line to yield the product (4.818 g, 98\%).

\section{5'-Azido-5'-deoxyuridine (14)}

With some modifications, a literature procedure was followed. ${ }^{27}$ Uridine $(5.00 \mathrm{~g}, 20.5 \mathrm{mmol})$, triphenylphosphine (8.05 g, $30.5 \mathrm{mmol})$, tetrabromomethane $(10.2 \mathrm{~g}$, $30.5 \mathrm{mmol})$, and lithium azide ( $3.695 \mathrm{~g}, 75.5 \mathrm{mmol}$ ) were stirred together in DMF $(100 \mathrm{ml})$ for $4 \mathrm{~h}$ at room temperature. The greater part of the solvent was removed under vacuum, and the residue was extracted with chloroform $(100 \mathrm{ml})$ and water $(100 \mathrm{ml})$, with the aqueous layer being retained. The aqueous layer was washed again with chloroform $(2 \times 100 \mathrm{ml})$ before being lyophilised. The viscous residue was purified by column chromatography, using an isocratic 5:1 mixture of chloroform and methanol. The resulting oil was dissolved in 5:1 chloroform-methanol and adsorbed on to a plug of silica, which was washed with $100 \%$ chloroform to remove residual DMF, then released using the $5: 1$ chloroform-methanol solution to yield the purified product. (3.70 g, 67\%); $\nu_{\max } / \mathrm{cm}^{-1} 2102\left(\mathrm{~N}_{3}\right), 1667$ (CO), 1462, $1386,1100\left(\mathrm{R}_{2} \mathrm{COH}\right) ; \delta_{\mathrm{H}}\left(500 \mathrm{MHz}, \mathrm{D}_{2} \mathrm{O}\right) 3.69(1 \mathrm{H}, \mathrm{dd}, J 13.7,5.0$, $\left.\mathrm{C}^{\prime}-\mathrm{H}_{\alpha}\right), 3.82\left(1 \mathrm{H}, \mathrm{dd}, J 13.7,3.2, \mathrm{C}^{\prime}-\mathrm{H}_{\beta}\right), 4.18-4.23(1 \mathrm{H}, \mathrm{m}$,
$\left.\mathrm{C}^{\prime}-\mathrm{H}\right), 4.27(1 \mathrm{H}$, app t, J 5.6, C' $3-\mathrm{H}), 4.42\left(1 \mathrm{H}, \mathrm{dd}, J 5.4,4.5, \mathrm{C}^{\prime}-\right.$ H), 5.89 (1H, d, J 4.4, C1'-H), $5.93(1 \mathrm{H}, \mathrm{d}, J$ 8.1, C5-H), $7.80(1 \mathrm{H}, \mathrm{d}$, $J$ 8.1, C6-H); $\delta_{\mathrm{C}}\left(126 \mathrm{MHz}, \mathrm{D}_{2} \mathrm{O}\right) 51.6,70.2,73.3,82.3,90.1,102.6$, 142.2, 151.7, 166.2; $\mathrm{m} / \mathrm{z} 268.0676(\mathrm{M}-\mathrm{H}, 30 \%)$, requires 268.0682, 304.0408 (100).

\section{$5^{\prime}$-Amino-5'-deoxyuridine, hydrochloride salt $(15 \cdot \mathbf{H C l})$}

Adapting a literature procedure, ${ }^{26} 5^{\prime}$-azido-5'-deoxyuridine (404 mg, $1.50 \mathrm{mmol}$ ) and triphenylphosphine were (1.66 g, 6.33 $\mathrm{mmol})$ were dissolved in pyridine $(1.6 \mathrm{ml})$ and stirred for $2 \mathrm{~h}$. Ammonia solution $(35 \%, 12 \mathrm{ml})$ was then added, and the mixture left to stir overnight. Water $(40 \mathrm{ml})$ was added, and the mixture was extracted with chloroform $(3 \times 40 \mathrm{ml})$. Residual chloroform was then removed from the aqueous layer under vacuum, and the remaining solution was lyophilised. The resulting powder was then dissolved in ethanol $(20 \mathrm{ml})$ and heated at reflux until dissolved. Hydrogen chloride gas was bubbled through the solution until precipitation occurred, and the pure hydrochloride salt was isolated by filtration and washing with a small quantity of ethanol. (329 $\mathrm{mg}, 78 \%$ ); $\mathrm{mp}$ 210-215 ${ }^{\circ} \mathrm{C}$ (decomp.) (from ethanol); $\nu_{\max } / \mathrm{cm}^{-1} 3040,1666$ (CO), 1464, 1042; $\delta_{\mathrm{H}}\left(700 \mathrm{MHz}, \mathrm{D}_{2} \mathrm{O}\right) 3.29-3.36\left(1 \mathrm{H}, \mathrm{m}, \mathrm{C5}^{\prime}-\mathrm{H}_{\alpha}\right)$, 3.44-3.49 (1H, m, C5' $\left.-\mathrm{H}_{\beta}\right), 4.22-4.26\left(2 \mathrm{H}, \mathrm{m}, \mathrm{C}^{\prime} 3-\mathrm{H}, \mathrm{C} 4^{\prime}-\mathrm{H}\right), 4.52$ $\left(1 \mathrm{H}, \mathrm{dd}, J 5.2,4.0, \mathrm{C} 2^{\prime}-\mathrm{H}\right), 5.77\left(1 \mathrm{H}, \mathrm{d}, J 4.0, \mathrm{C}^{\prime}-\mathrm{H}\right), 5.89(1 \mathrm{H}, \mathrm{d}, J$ 8.0, C5-H), $7.66\left(1 \mathrm{H}, \mathrm{d}, J\right.$ 8.1, C6-H); $\delta_{\mathrm{C}}\left(126 \mathrm{MHz}, \mathrm{D}_{2} \mathrm{O}\right) 41.8$, $71.4,73.2,80.0,93.3,102.8,143.9,152.0,166.9 ; \mathrm{m} / \mathrm{z} 244.0934$ (M- H, 100\%), requires 244.0933 .

\section{Phosphorylating agents}

The preparation of potassium phosphodichloridate and potassium thiophosphodichloridate has been reported previously. ${ }^{20,34}$

\section{Phosphorylation procedure}

The aminonucleoside $(0.500 \mathrm{mmol})$ was placed in a thermostated reaction flask maintained at $25{ }^{\circ} \mathrm{C}$ and water and potassium hydroxide were added as required to make a $5 \mathrm{ml}$ solution at the desired $\mathrm{pH}$. The phosphorylating agent $(1.50 \mathrm{ml}$, $0.333 \mathrm{M}$ in $\mathrm{MeCN}$ ) was added using a Hamilton ${ }^{\circledR}$ microlitre syringe. The addition took place over $10 \mathrm{~min}$ with vigorous stirring, and with the tip of the syringe below the surface of the reaction mixture. Throughout the experiment, the $\mathrm{pH}$ was kept constant using a $1 \mathrm{M}$ solution of potassium hydroxide, added by the autotitrator system. The experiment was considered to be complete when the autotitrator needed to add negligible quantities of potassium hydroxide solution to the reaction mixture. After the completion of the reaction, the organic solvent was removed under vacuum and aqueous remainder was lyophilised.

\section{Alkylation procedure}

Aqueous solutions $(5 \mathrm{ml})$ of $5^{\prime}$-amino-5'-deoxyguanosine thiophosphoramidate $114(28.2 \mathrm{mg})$ were made up in the thermostated reaction flask at a concentration of $20 \mathrm{mM}$ at the desired $\mathrm{pH}$, and were vigorously stirred at $25^{\circ} \mathrm{C}$. Methyl iodide $(14.3 \mu \mathrm{l})$, benzyl chloride $(26.5 \mu \mathrm{l})$ or bromoethanol $(12.4 \mu \mathrm{l})$ alkylating 
agent was then added to the reaction solution via Hamilton ${ }^{\circledR}$ syringe and stirred for $1 \mathrm{~h}$. The excess alkylating agents were removed by extraction with diethyl ether $(3 \times 10 \mathrm{ml})$ and the aqueous solution was subsequently lyophilised. The conversions of $5^{\prime}$-amino- $5^{\prime}$-deoxyguanosine thiophosphoramidate to alkylated thiophosphoramidate product were estimated by ${ }^{31} \mathrm{P}$ NMR spectroscopy. Where the products of the alkylation were isolated, the lyophilised crude material was redissolved in water $(4 \mathrm{ml})$ and purified by anion exchange chromatography with a flow rate of $5 \mathrm{ml} \mathrm{min}{ }^{-1}$ over a DEAE-Sepharose $®$ resin. Triethylammonium bicarbonate buffer was applied in a 0 to $0.15 \mathrm{M}$ gradient over $200 \mathrm{~min}$. The fractions corresponding to peaks in the UV-vis absorbance were collected and lyophilised.

\section{5'-Amino-5'-deoxyguanosine, $\mathrm{N}$-, $\mathrm{S}$ -} methylthiophosphoramidate, triethylammonium salt (22a)

After purification, a small quantity of by-product $\left(\mathrm{MeSPO}_{3}{ }^{2-}\right.$, $<10 \%$ mol basis by ${ }^{31} \mathrm{P}$ NMR spectroscopy) remained. $47 \mathrm{mg}$, 95\%; $\delta_{\mathrm{H}}\left(400 \mathrm{MHz}, \mathrm{D}_{2} \mathrm{O}\right) 1.26\left(9 \mathrm{H}, \mathrm{t}, J 7.3, \mathrm{HN}^{+}\left(\mathrm{CH}_{2} \mathrm{CH}_{3}\right)_{3}\right), 2.08$ (3H, d, J13.0, $\left.\mathrm{CH}_{3} \mathrm{~S}\right), 2.94-3.28\left(2 \mathrm{H}, \mathrm{m}, \mathrm{C}^{\prime}-H_{2}\right), 3.18(6 \mathrm{H}, \mathrm{q}, J 7.3$, $\left.\mathrm{HN}^{+}\left(\mathrm{CH}_{2} \mathrm{CH}_{3}\right)_{3}\right), 4.31-4.35\left(1 \mathrm{H}, \mathrm{m}, \mathrm{C}^{\prime}-H\right), 4.41$ (1H, app d, J 5.6, $\left.\mathrm{C}^{\prime}-H\right), 5.08\left(1 \mathrm{H}, \mathrm{dd}, J 8.0,5.6, \mathrm{C}^{\prime}-H\right), 5.76\left(1 \mathrm{H}, \mathrm{d}, J 8.0, \mathrm{C}^{\prime}-H\right)$, $7.87(1 \mathrm{H}, \mathrm{s}, \mathrm{C} 8-H) ; \delta_{\mathrm{C}}\left(101 \mathrm{MHz}, \mathrm{D}_{2} \mathrm{O}\right) 8.3,11.4,43.4,46.7,71.4$, 86.0, 88.8, 100.0, 117.2, 139.8, 151.3, 153.7, 159.0; $\delta_{\mathrm{P}}(162 \mathrm{MHz}$, $\left.\mathrm{D}_{2} \mathrm{O}\right) 26.3 ; \mathrm{m} / \mathrm{z} 391.0597\left(\mathrm{M}-\mathrm{Et}_{3} \mathrm{NH}^{+}, 100 \%\right)$, requires 391.0590, 392.0627 (20), 393.0617 (10).

\section{$5^{\prime}$-Amino-5'-deoxyguanosine, $\mathrm{N}$-, $\mathrm{S}$ -}

benzylthiophosphoramidate, triethylammonium salt (22b)

After the purification procedure, some by-product $\left(\mathrm{BnSPO}_{3}{ }^{2-}\right.$, $\sim 10 \%$ mol basis by ${ }^{31} \mathrm{P}$ NMR spectroscopy) remained. $36 \mathrm{mg}$, $63 \% ; \delta_{\mathrm{H}}\left(400 \mathrm{MHz}, \mathrm{D}_{2} \mathrm{O}\right) 1.25\left(9 \mathrm{H}, \mathrm{t}, J 7.3, \mathrm{HN}^{+}\left(\mathrm{CH}_{2} \mathrm{CH}_{3}\right)_{3}\right), 2.80-$ $3.20\left(2 \mathrm{H}, \mathrm{m}, \mathrm{C}^{\prime}-\mathrm{H}_{2}\right), 3.17\left(6 \mathrm{H}, \mathrm{q}, J 7.3, \mathrm{HN}^{+}\left(\mathrm{CH}_{2} \mathrm{CH}_{3}\right)_{3}\right), 3.80-3.88$ (2H, m, $J$ 5.6, $\left.\mathrm{SCH}_{2} \mathrm{Ph}\right), 4.18-4.22\left(1 \mathrm{H}, \mathrm{m}, \mathrm{C}^{\prime}-\mathrm{H}\right), 4.33(1 \mathrm{H}, \mathrm{dd}, J$ 5.6, 1.6, C3'-H), 5.10 (1H, dd, J 7.9, 5.6, C2'-H), 5.66 (1H, d, J 7.9, $\left.\mathrm{C1}^{\prime}-\mathrm{H}\right) 6.99$ (1H, t, J 7.1, o-ph), $7.06(2 \mathrm{H}, \mathrm{t}, J 7.1, m-\mathrm{ph}), 7.24(2 \mathrm{H}, \mathrm{d}$, $J$ 7.1, o-ph) $7.82(1 \mathrm{H}, \mathrm{s}, \mathrm{C} 8-\mathrm{H}) ; \delta_{\mathrm{C}}\left(101 \mathrm{MHz}, \mathrm{D}_{2} \mathrm{O}\right) 8.2,10.5,43.3$, 46.6, 59.0, 70.9, 71.5, 85.7, 88.7, 117.2, 126.6, 128.2, 138.6, 139.9, 151.3, 153.5, 158.9; $\delta_{\mathrm{P}}\left(162 \mathrm{MHz}, \mathrm{D}_{2} \mathrm{O}\right) 24.1 ; \mathrm{m} / z 467.0899(\mathrm{M}-$ $\mathrm{Et}_{3} \mathrm{NH}^{+}, 100 \%$ ), requires 467.0903, 468.0936 (20), 469.0919 (10).

$5^{\prime}$-Amino-5' -deoxyguanosine, $N$-, $S$-ethan-2olthiophosphoramidate, triethylammonium salt (22c)

$39 \mathrm{mg}, 74 \% ; \delta_{\mathrm{H}}\left(400 \mathrm{MHz}, \mathrm{D}_{2} \mathrm{O}\right) 1.35\left(9 \mathrm{H}, \mathrm{t}, J 7.3, \mathrm{HN}^{+}\left(\mathrm{CH}_{2} \mathrm{CH}_{3}\right)_{3}\right)$, $2.88\left(2 \mathrm{H}, \mathrm{dt}, J\right.$ 12.7, 6.4, $\left.\mathrm{SCH}_{2} \mathrm{CH}_{2} \mathrm{OD}\right), 3.26(6 \mathrm{H}, \mathrm{q}, J$ 7.3, $\left.\mathrm{HN}^{+}\left(\mathrm{CH}_{2} \mathrm{CH}_{3}\right)_{3}\right), 3.79\left(2 \mathrm{H}, \mathrm{t}, J 6.4, \mathrm{SCH}_{2} \mathrm{CH}_{2} \mathrm{OD}\right), 4.43(1 \mathrm{H}, \mathrm{dd}, J 2.9$, 1.6, C4'-H), 4.50 (1H, dd, J 5.6, 1.6, C3'-H), 5.18 (1H, dd, J 8.0, 5.6, C2'-H) $5.86\left(1 \mathrm{H}, \mathrm{d}, J\right.$ 8.0, C1'-H), $7.95(1 \mathrm{H}, \mathrm{s}, \mathrm{C} 8-\mathrm{H})$; $\delta_{\mathrm{C}}(101 \mathrm{MHz}$, $\left.\mathrm{D}_{2} \mathrm{O}\right)$ 8.3, 10.6, 31.9, 43.4, 46.7, 61.5, 71.4, 85.9, 88.7, 117.4, 139.4, $151.3,155.0,160.5 ; \delta_{\mathrm{P}}\left(162 \mathrm{MHz}, \mathrm{D}_{2} \mathrm{O}\right) 24.9 ; \mathrm{m} / z 421.0679(\mathrm{M}-$ $\left.\mathrm{Et}_{3} \mathrm{NH}^{+}, 100 \%\right)$, requires 421.0695, 422.0733 (20), 443.0501 (10).

\section{Analysis}

The solid residues resulting from the experiments were dissolved in $750 \mu \mathrm{l}$ or the minimum volume of $\mathrm{D}_{2} \mathrm{O}$, whichever was less, and analysed by NMR spectroscopy to determine conversion. The conversion levels were determined using all the peaks visible by ${ }^{31} \mathrm{P}$ NMR spectroscopy with a relaxation time of $10 \mathrm{~s}$, acquisition time of $1.28 \mathrm{~s}$, and 128 transients. ${ }^{1} \mathrm{H}$ NMR spectra were also recorded. The ${ }^{31} \mathrm{P}$ NMR spectroscopic chemical shifts of the phosphoramidate and thiophosphoramidate products of the reaction were found to be consistent with those determined in our previous work. ${ }^{15,19,22}$ The changes in chemical shifts of the ${ }^{1} \mathrm{H}$ NMR signals corresponding to the $5^{\prime}$ or $3^{\prime}$ protons (depending on the substrate) of $\sim 0.5 \mathrm{ppm}$ upfield, and the increase in multiplicity through coupling to phosphorus corroborated the formation of the desired phosphoramidates and thiophosphoramidates.

\section{Acknowledgements}

This work was supported by EPSRC DTA funding (LPC and RJD), the Royal Society and Durham University.

\section{Notes and references}

1 S. Spitzer and F. Eckstein, Nucleic Acids Res., 1988, 16, 1169111704.

2 J. K. Chen, R. G. Schultz, D. H. Lloyd and S. M. Gryaznov, Nucleic Acids Res., 1995, 23, 2661-2668.

3 A. Grandas, W. S. Marshall, J. Nielsen and M. H. Caruthers, Tetrahedron Lett., 1989, 30, 543-546.

4 H. J. Korhonen, L. P. Conway and D. R. W. Hodgson, Curr. Opin. Chem. Biol., 2014, 21, 63-72.

5 A. Hampton, Biochim. Biophys. Acta, 1970, 198, 594-600.

6 A. Hampton, L. W. Brox and M. Bayer, Biochemistry, 1969, 8, 2303-2311.

7 A. B. Burgin and N. R. Pace, EMBO J., 1990, 9, 41114118.

8 G. Sengle, A. Jenne, P. S. Arora, B. Seelig, J. S. Nowick, A. Jaschke and M. Famulok, Bioorg. Med. Chem., 2000, 8, 1317-1329.

9 M. Skipsey, G. Hack, T. A. Hooper, M. C. Shankey, L. P. Conway, M. Schröder and D. R. W. Hodgson, Nucleosides, Nucleotides Nucleic Acids, 2013, 32, 670681.

10 E. Paredes, M. Evans and S. R. Das, Methods, 2011, 54, 251259.

11 V. J. Davisson, D. R. Davis, V. M. Dixit and C. D. Poulter, J. Org. Chem., 1987, 52, 1794-1801.

12 M. Yoshikawa, T. Kato and T. Takenishi, Bull. Chem. Soc. Jpn., 1969, 42, 3505-3508.

13 J. Nielsen, M. Taagaard, J. E. Marugg, J. H. Vanboom and O. Dahl, Nucleic Acids Res., 1986, 14, 7391-7403.

14 D. Williamson and D. R. W. Hodgson, Org. Biomol. Chem., 2008, 6, 1056-1062.

15 D. Williamson, M. J. Cann and D. R. W. Hodgson, Chem. Commun., 2007, 5096-5098.

16 M. Trmcic and D. R. W. Hodgson, Chem. Commun., 2011, 47, 6156-6158. 
17 K. Schattka and B. Jastorff, Chem. Ber./Recl., 1974, 107, 30433052.

18 B. Jastorff and H. Hettler, Chem. Ber./Recl., 1969, 102, 41194127.

19 M. Trmčić and D. R. W. Hodgson, Chem. Commun., 2011, 47, 6156-6158.

20 R. J. Delley, A. C. Donoghue and D. R. W. Hodgson, J. Org. Chem., 2012, 77, 5829-5831.

21 D. K. Dean, Synth. Commun., 2002, 32, 1517-1521.

22 M. Trmcic, F. L. Chadbourne, P. M. Brear, P. W. Denny, S. L. Cobb and D. R. W. Hodgson, Org. Biomol. Chem., 2013, 11, 2660-2675.

23 S. J. Benkovic and E. J. Sampson, J. Am. Chem. Soc., 1971, 93, 4009-4016.

24 Nucleic Acids in Chemistry and Biology, ed. G. M. Blackburn and M. J. Gait, Oxford University Press, New York, 2 edn, 1996.

25 M. Kolb, C. Danzin, J. Barth and N. Claverie, J. Med. Chem., 1982, 25, 550-556.
26 P. Cano-Soldado, M. Molina-Arcas, B. Alguero, I. Larrayoz, M. P. Lostao, A. Grandas, F. J. Casado and M. PastorAnglada, Biochem. Pharmacol., 2008, 75, 639-648.

27 I. Yamamoto, M. Sekine and T. Hata, J. Chem. Soc., Perkin Trans. 1, 1980, 306-310.

28 K. A. Watanabe and J. J. Fox, Angew. Chem., Int. Ed., 1966, 5, 579-580.

29 K. A. Winans and C. R. Bertozzi, Chem. Biol., 2002, 9, 113129.

30 M. G. Stout, M. J. Robins, R. K. Olsen and R. K. Robins, J. Med. Chem., 1969, 12, 658-661.

31 G. H. Jones, M. Taniguchi, D. Tegg and J. G. Moffatt, J. Org. Chem., 1979, 44, 1309-1317.

32 P. S. Ludwig, R. A. Schwendener and H. Schott, Synthesis, 2002, 2387-2392.

33 R. Steudel and P. W. Schenk, in Handbuch der Präparativen Anorganischen Chemie, ed. G. Brauer, Ferdinand Enke Verlag, Stuttgart, 1975, 1, p. 475.

34 Y. Segall, J. Agric. Food Chem., 2011, 59, 2845-2856. 